\title{
Invisible Women in History and Global Studies: Reflections from an Archival Research Project
}

\section{Meenal Shrivastava}

Athabasca University, Alberta, Canada

\begin{abstract}
This article questions the continuing invisibility of the significant scale of the involvement of women in historical movements/moments. The focus is on Mahatma Gandhi-led Civil Disobedience movement (1930-33), which was a historic turning point enabling the political involvement of masses of women in South Asia. Using an individual narrative, multiarchival research, and secondary literature survey, this article contends that the thriving subaltern and feminist historical traditions have had limited impact on historical 'gender mainstreaming' Furthermore, the paper argues that revealing the diverse nature and the substantial scale of women's involvement in social/political change is important for two reasons: firstly, it contributes to a fuller understanding of history and; secondly, because historical research is essential for contemporary policy-making. Reclaiming the role of ordinary women in disparate history writing traditions thus can be a tool to understand and counter persistent gender inequality, in South Asia and in the larger global community.
\end{abstract}

Keywords: Global History, Gendered History, Subaltern Studies, Indian Freedom Movement, Women's Political Activism, History and Policy

\author{
"Men have singled out women of \\ outstanding merit and put them on a \\ pedestal to avoid recognizing the \\ capabilities of all women." \\ (Huda Shaarawi, writer and women's \\ rights organizer, 1924, Egypt)
}

\section{Introduction: The Erasure of Millions}

Subaltern Studies exposed the breach between popular and national histories by pointing to the construction of history as a process that is driven by the social and political elite of the time. From a research model for studying the colonial experience of South Asia, Subaltern Studies has provided a method of vigorous post-colonial critique, significantly enriching the 
texture and interpretation of historical research. This approach revolutionized Indian historiography in particular by challenging nationalistic frames and expanding the subject matter of history beyond the machinations of dynasties, leaders and rulers, to autonomous popular movements defining 'a history from below' (see Sarkar 1983a, 1998; Ludden 2002). Subaltern historians searched for the roots of the profoundly ambiguous and contradictory patterns of continuities and change in the Indian subcontinent by expanding the scope of history through the inclusion of the role of trade unions, tribal revolts, peasant groups and a nascent capitalist bourgeoisie.

Aside from these groups, however, there was another significant demographic which led to the irreversible entry of the masses into active political life: the multitude of South Asian women. Ordinary women's lives were not only being transformed by the national movement within and outside the domestic spheres, but women themselves were contributing to the eventual emergence of the world's largest mass movement. Nevertheless, one of the earliest and very influential texts in this tradition, Sumit Sarkar's Modern India: 1885-1947 (1983b) contains one paragraph on the role of women. Indeed, this neglect has been subsequently supplemented by an incredible wealth of research on women's history, both from the perspective of Subaltern Studies and feminist analysis.

The rise and evolution of subaltern studies and feminist analysis of history notwithstanding, data on women's participation in human history, in South Asia and elsewhere, remains sketchy. This is particularly vexing in the context of the fact that in the first year of the Salt Satyagraha alone (1930-31), of the 80,000 people imprisoned for acts of civil disobedience, 17,000 were women (see Thomas 1964; Forbes 1999). During the Indian Civil Disobedience movement in the 1930s, women participated not only in political rallies, protest marches, and picketing expeditions, but a large number of women also served various lengths of prison sentences under the treason or sedition acts (Section 121 and Section 124A). Despite this unprecedented level of political participation by women, even after nearly six decades of political independence, the nature and scale of ordinary women's participation remains invisible within the Nationalist traditions of South Asian historiography. More surprisingly, this substantial scale of women's involvement finds little acknowledgement in the Indian `subaltern' traditions or even the 'global' feminist narratives.

In the context of the new patriarchy that emerged in post-independence India, which saw women excluded from political power, Partha Chatterjee (1989) discusses the reasons and mechanisms for the erasure of women from historical accounts. This much-debated analysis is part of a trend that brought back the women's question in subaltern studies (Spivak 1985; O’Hanlon 1988; Bannerji 200; Kapur 2000; Menon 2007). Nevertheless, despite a huge uptake in the critiques of women in the subaltern project, these works remained uninterested in women nationalists. Consequently, the presence, voices, and agency of non-elite women in the various battles for freedom and equality remains unaccounted for. Hence we know little about the 
ordinary women political activists whose lives were fundamentally transformed by their political involvement and who transformed the very nature of the independence movement in South Asia.

Notwithstanding some notable efforts to uncover their stories in the subaltern and feminist traditions (see for instance Jena, 1999; Sangari \& Vaid, 1990; Thapar-Björkert, 2006; Fletcher, Levin, \& Mayhall, 2014), throngs of ordinary women who formed a crucial part of the first generation of modern South Asian political activism remain largely invisible; the exception being a handful of women with famous male relatives. This trend is particularly vexing in the Indian context, where despite being the birthplace of Subaltern Studies, a volume on 'Indian Women Freedom Fighters' starts with the views of prominent men on the role of women in the society, and ends with short biographies of a few women leaders with eminent family names, the later section comprising less than a third of the book (see Agarwal 2008).

Using the findings of a research project on the anti-colonial movement in British India, this article relates a personal journey of discovery underscoring the significance of individual narratives and archival resources. Both the Subaltern Studies and the feminist traditions have long recognized the importance of personal narratives, family histories, and oral histories contributing to a fuller understanding of the history of popular movements. The paper contends that these inclusive theoretical and methodological approaches have had limited application in contemporary historiography, in South Asia and elsewhere. Therefore, the paper argues for gender mainstreaming across various historiographical approaches - not only those on the right and left of the political spectrum but also the 'global' feminist narratives. This is important not only for a more comprehensive understanding of history, but also because our understanding of the past has direct relevance for contemporary social policy issues.

\section{Historical Serendipity}

The erasure of women is neither unique to South Asian history nor to Indian historiography (see Holmes 2010; Holmes 2014). Globally, ‘women’ has been either a marginal topic, or a separate subject of history writing. Although, history of women as a field of enquiry arose in the 1960s producing some significant correctives to traditional history writing that had obscured the role of women in social and political change (Lerner 1994, 2005; Fletcher et al, 2014), this did not lead to any significant inclusion of women in mainstream history writing (see for instance Barnett 1993; Díaz-Andreu \& Sorensen 2013), even less so in accounting for the invisible women of colour in Clio's Empire ${ }^{1}$.

The invisibility of ordinary women of colour in the "global" history of the modern feminist movement is particularly glaring. Mainstream accounts of feminism consider its beginnings in the women's suffrage movements in the western world in the $19^{\text {th }}$ and $20^{\text {th }}$ Centuries, spreading to the post-colonial world only after the 1960s. Clearly the smooth edges of mainstream historical narratives, even feminist ones, are ruffled by allowing spaces for the stories of erased women from different parts of the world. The need for this ruffling is evident 
when we consider the fact that the 1928 lowering of the voting age of British women to give them equal suffrage with men in the UK (see Childs 2008) coincided with the repression of civil liberties in British India during the same period (see Bakshi 1977).

The appointment of the Simon Commission for constitutional reform in India without any Indian representation, and its arrival in India in 1928, led to nationwide protests, which the British authorities tried to curb through extreme police brutality and the suspension of civil liberties. The political stalemate on the issue of representation and police brutality led to Gandhi's call for nationwide Civil Disobedience in 1930. Gandhi not only led one of the largest non-violent mass movements in the world, but also opened the doors for an unprecedented number of ordinary South Asian women to join the freedom movement, which included a 12 year old girl, my grandmother, Prakashwati Sinha, aka as Parvati or Shanti Devi. The need for the historical authentication of her personal diary (Sinha n.d) and published autobiography (Sinha 1962) led to my archival quest, a narrative memoir ${ }^{2}$, and the conference papers ${ }^{3}$ on which this article is based.

\subsection{A Reluctant Story-teller}

In 2010, after my mother lost her fight with cancer, I reluctantly inherited the kernel of her ever-deferred writing project, the extraordinary story of her freedom-fighter parents. Out of sheer convenience, my research focused on my grandmother, whose public figure and eloquent writings made it relatively easier to collect supplementary historical materials, compared to my mysterious grandfather, whose stubborn silence wrapped his revolutionary past under secret layers that are much harder to unravel. A Master's degree in Modern Indian History had introduced me to the array of the historiography of the Indian National Movement, which partially informed my assumption that my grandmother was one of a handful of political women on the margins of the South Asian anti-colonial movement.

Using a lifetime of oral history, my mother's and grandmother's diaries, and the body of their published work (Sinha n.d, 1962; Sinha, 2008a, 2008b, 2008c, 2011) as the starting points, I used my sabbatical to conduct secondary and archival research to understand the life and times of my grandmother. This required sifting through large amounts of archival materials ${ }^{4}$ to authenticate the haphazard series of dates and events in the written accounts, and to find evidence and context for the oral history; all of these supplemented by a secondary literature survey.

I was surprised to learn that my grandmother was not among a handful of women political activists, but one among the many hundreds of thousands of women without a famous last name who made up the cadre of the freedom movement in South Asia. The story of my grandmother's life was indeed unique for running away at the age of eight from her privileged family home following a personal trauma; for joining a revolutionary group in the late 1920s and working 'underground' for about eighteen months; for being jailed for sedition at the age of 
twelve in Ajmer; for being imprisoned twice more before she turned fifteen years old; for finding refuge in Gandhi's ashram in Wardha at the age of sixteen to reinvent her life under yet another name and as the Principal of Kasturba Girls' School (Kanya Pathshala); for being briefly and intensely courted by Pandit Parmanand, the longest serving political prisoner in colonial India, but then marrying another disenchanted revolutionary, Rajeshwer Narayan Sinha; for not giving up on the ideals of social justice even after the botched and violent processes of independencewith-partition and surviving four difficult years as one of the few women bureaucrats in the newly created UP Social Welfare Department; for finding relative stability as the founderPrincipal of Veer Balika Girl's High School; and for raising her two daughters in the largely feudalistic environs of Jaipur after independence, far from her family and without much help from her rather unconventional spouse $\mathrm{s}^{5}$.

At the time of writing this article, I had just finished writing a narrative biography Amma's Daughters (Shrivastava, in Press) as 'Historical Fiction', acutely aware that it is much more than the story of an individual. My grandmother's diaries allude to the precarious but generous support from the vast, uneven, and informal network of men and women, which allowed her to acquire an education on the run, and to learn to wield the pen along with her kirpan dagger to stave off the many assaulters she encountered. Until she found the protection of the political glitterati of Gandhi's ashram, her mentors included many middle class educators, minor lawyers, journalists, physicians, and other urban bourgeoisie. Away from the limelight, these men and women quietly operated under the turbulent political milieu, nurturing and protecting political activists of various stripes spread across the subcontinent. Her survival was not possible though, without the complicity and active participation of the women who ran the households of her benefactor - mothers, sisters, wives, and aunts, whose courageous actions within the fore walls converted a political movement into a truly mass movement.

More importantly, her diaries also recorded numerous stories of overt political activism by ordinary women who often paid a high personal price for their audacity. Rejected by their families, many of these women formed close-knit relationships with each other to sustain themselves, forming the basis for many ongoing intergenerational relationships ${ }^{6}$. The reasons and mechanisms for the resilience of these relationships across castes/regions/religion/and class are only vaguely remembered. The courageous women who forged these unusual relationships for self-preservation were also indispensable pieces of the scaffolding which created the massive edifice connecting the great nationalist leaders to the far reaches of the subcontinent. Once independence was achieved, the scaffolding was dismantled and its pieces retreated into the relative safety of public oblivion, receiving little acknowledgement for the role they played in the freedom of their country. Their stories are languishing in personal diaries, private letters, photographic chronicles, oral traditions, and other records that are yet to be fully utilized as historical material. 
During her time in Jaipur (1945-1972), my grandmother was among a small number of women with a significant public profile as a committed social activist, an educationist, and an active member of the Congress women's forum (Mahila Samiti) and the Jaipur City Council. She died of her third heart attack at the age of fifty-four in 1972. Despite the public acknowledgement of her role in the freedom movement, my grandmother remained hesitant to divulge much about her eventful childhood. Her copious writings are silent about the family of her birth and her time with the revolutionaries (clearly driven by the desire to protect the people in her past as well as to avoid possible social repercussions for her daughters). Following the many stories handed down by my mother, and the many associates of my grandmother whom I met, a close reading of her writings revealed a number of clues though. I was able to authenticate many of these strands through archival research ${ }^{7}$. Her published autobiography (Sinha 1962) contains sanitized excerpts from the copious amount of diary entries she wrote and preserved. Scores of daily diaries contained harrowing details of her various encounters with physical and emotional violence. Unfortunately, only one of her personal diary (Sinha n.d) has survived the benign neglect of two generations that only belatedly learnt the significance of individual accounts in broadening historical understanding ${ }^{8}$.

What emerged from the multi-archival research in London, New Delhi, and Patna, challenged my assumptions about the nature and scale of women's involvement in the national movement in South Asia. Wives, daughters, and nieces of famous political activists who found themselves in the midst of social-political upheaval in South Asia, were often thrust into leadership roles during the most restive periods of political mobilization. The courageous actions of this handful of women are rightfully celebrated in historical texts, particularly those written in the Nationalist tradition. As shown later in this article, however, the stories of these elite women are not truly representative of the experience of the majority of women political activists of the time. In fact, the dominance of the historical accounts of elite women has acted like a foil hiding the very different lived experience of masses of women who participated in the freedom movement. This historical oversight distorts the true nature and scale of women's contributions to and involvement in the largest non-violent political movement in the world.

\subsection{Where Were the Women?}

Long before Mahatma Gandhi led a sub-continent wide movement against the colonial policies of the British, ordinary women were supporting families of nationalists who were in prisons, or in hiding from the police. There are, for instance, numerous local newspaper microfilms that record instances of numbers of women showing up to express support to the family of incarcerated nationalists during revolutionary movements, such as the Anushilan Samiti and Jugantar, which arose in response to the 1905 partition of Bengal. Without any formal integration of women in political institutions, these ordinary women had been involved in unrecognized acts of political defiance in various periods of the national movement, proving the suspicion of the British that the zenanas were nurturing dangerous political notions (Chirol, as quoted in Forbes 1988, 59). 
Several disastrous colonial policies later, Gandhi's domestication of the political space by using imageries of filial relationships (Bapu, Ba, Bharat Mata) is well documented (see for instance Desai \& Thakkar 2001; Thapar-Björkert 2006). Such imagery was indeed an effective political mechanism that created the social and political space to enable the mass participation of women in the Civil Disobedience movement. Indeed the struggle for independence did not just shake the foundations of the British Empire but also of the deeply paternalistic society on the Indian subcontinent.

Nevertheless, while significant scholarship exits on the historical context in which the identity of the Indian woman emerged and evolved, aside from a few notable exceptions (see Sinha 2006 and 2008; Legg 2003 and 2014; Jenna 1999; Tharu \& Lalita 1991; Basu \& Ray 1990), research to uncover ways in which it transformed the lives of ordinary men and women is still lacking. There is indeed no dearth of historical texts on the nineteenth-century middle class social reforms on issues concerning the oppression of women in the Indian culture ${ }^{9}$. In the twentieth-century, however, social issues were relegated to the national movement, which arguably led to a rather abrupt disappearance of women's issues from public debate (see Chatterjee 1993). Gender scholars have highlighted the simultaneous proliferation of discourses about women and their surprising marginalization in these same discourses, noting that a concerted examination of the voices of the disparate Indian womanhood is often missing in the extensive research on the gender politics of colonialism and nationalism (see for instance, Sangari \& Vaid 1990).

Not unlike in the rest of the world, my preliminary research revealed that neither the scale of women's involvement, nor the variegated nature of their historical experience finds much acknowledgement in mainstream Indian historiography. These omissions could lead to several questions: Despite the high proportion of women's political participation in most regions of South Asia, as well as robust scholarship on 'women's history' and the politics of feminism in colonial India, why is the role of women so understated in the mainstream historiography of the anti-colonial movement? What were the social and political mechanisms enabling the erasure of the masses of women from the stories of the anti-colonial movement in South Asia? What role have these patterns played in the persistence of gender inequality in the region? What do historical patterns tell us about contemporary policy debates, designs, and implementation issues? Given their broad nature, these questions are not necessarily answered in this article. However, pointing to these particular aspects of the erasure of women from history could potentially contribute to broadening the historical understanding of contemporary processes and conditions.

Combining the need for authenticating the written and oral histories of my grandmother and to establish a sense of long-term patterns of the nature and scale of women's political participation, I conducted a limited archival survey with a focus on the Civil Disobedience Movement. My survey included microfilms of local and national Hindi and English language newspapers from the United Province, such as: Aaj (Varanasi), Indian Daily Telegraph 
(Lucknow), Leader (Allahabad), Pratap (Cawnpur), Sainik (Agra), and Sangharsh (Lucknow). It also included a random selection of All India Congress Committee Bulletins, Indian Nation, Hindi Pracharak, and Yugantar magazines from this period.

The richest source of information about political activities among the grassroots proved to be the declassified 'secret reports by agents of the provincial governors'. I confined my searches to the fortnightly reports which recorded acts of civil disobedience from 1930 to 1933 in Ajmer-Merwara, United Province, and Bihar and Orissa, for regional consistency. Undoubtedly, this limited survey barely maps the tip of the iceberg, since there is a vast treasure of vernacular magazines, sporadic newsletters, occasional pamphlets, and private correspondences languishing in public and private archives that are yet to be deployed as historical materiel. While the surveyed sources above helped confirm the numeric patterns of the political involvement of ordinary women and provided some not-so-famous names ${ }^{10}$, this research also highlighted that the memories, voices and experiences of thousands of these women remain unexplored in family histories, personal journals, and oral histories.

My impressionistic survey of the archival materials consistently showed a recurring ratio of political prisoners as follows: 150-170 men, 40-50 women, 15-20 children. My sample survey also revealed that the popularity of husband, or any male relative, was critical for a woman to be acknowledged or 'named' in newspaper articles, government reports, (and later even text books on Indian history). For instance, although the surveyed newspapers regularly published stories about famous wives, daughters, and nieces, the same newspapers only mentioned the numbers of "non-prominent" women in jails, never their names or other identifiers.

Perhaps the obscuring of women's identities was the result of a deep-seated patriarchal instinct to protect women activists on the part of the editors of these newspapers, many of whom were staunch nationalists and nearly all were men. Additionally, and unsurprisingly, even the declassified official reports which mention the number of men, women, and children arrested and/or sentenced for acts of civil disobedience only named "prominent persons convicted". The only women mentioned by name in newspaper or official reports were the ones with famous husbands or fathers. As a result, aside from a handful of elite women, the female foot soldiers of the complex saga of the independence movement in the subcontinent remain nameless and faceless.

Clearly, naming could also lead to shaming, especially if the women activists had no recognizable pedigree. The vilification and public humiliation of women who bore the triple constraints of gender, race and class ${ }^{11}$, are starkly brought out in the well documented Benares Women Volunteer case in 1932. Women political volunteers were assaulted, publically humiliated, and wrongfully imprisoned. Yet the accused policemen were honourably acquitted after an internal inquiry, despite the interventions of senior Congress leaders such as Madan Mohan Malviya and Sarojini Naidu (National Archives of India 1932). The official investigation 
by the British superintendent of police, and later by the British district magistrate, found the policemen blameless. The magistrate declared the victims of violence as being of morally dubious character for not being married and for their propensity to venture in public without any male escorts.

The difference between the treatments of women activists of various classes is also bluntly laid out in official circulars outlining proposals to discourage 'prominent women' political activists (British Library 1931). The report recommends hiring of 'untouchable' women in prisons to deter 'high-caste' women from offering arrests, since this would go against the social taboo of mixing of castes. Other suggestions included hefty monetary fines to be paid by the male relatives or guardians. An example of the sharp contrast between prison conditions for 'prominent' women political prisoners and non-elite women is found in the autobiographical accounts of my grandmother. Her prison experiences as a teenager without political patronage included assaults, deprivations, and solitary confinements (Sinha 1962 and Sinha n.d). Without any hint of irony, my grandmother also recorded the affectionate generosity of a famous political prisoner, the wife of a prominent Congress leader. My grandmother shared part of her sentence in the Allahabad jail with a famous wife, who insisted on sharing with the fifteen year old inmate home-cooked meals delivered by her personal cook.

Life outside the prison was equally dangerous for young women without the protection of famous family names. Until after she got married, and was regarded as 'out of bounds' by suitors, my grandmother wore a kripan dagger in a very visible shoulder belt to ward off unwanted advances and physical assaults. In her diaries, my grandmother recorded two assaults before she turned sixteen, both resulting in her stabbing the assaulter in self-defence.

These are but a few examples of the experience of the subaltern of the subaltern - young South Asian women without political patronage, who often lost the protection of their family name and support for joining the battles of independence. In this context, Gyanendra Pandey (2011) asks a question pertinent to the neglect of women in different accounts of emancipation/assimilation: What if the paradigmatic examples are taken to be groups that have often been described as "different” in modern historical and political discourse, such as Dalits, blacks or (non-elite) women. The answer(s) to this question will not only broaden our historical horizons, but it can also shed light on the persistence of unequal and unjust patterns in contemporary society. Undoubtedly, the inadequately challenged binaries of political/personal, political activist/passive victim, and public/private spaces, have contributed to the erasure of ordinary women and their personal activism from public historical accounts. As the next section contends, however, while critical scholarship, particularly arising out of the subaltern and feminist traditions, acknowledge the limitations of these binaries, the insights from these studies have not necessarily made an impact on the research agendas in different historiographical traditions. Highlighting the relevance of history for policy design and analysis, I argue that 
revealing the role of ordinary women in historical movements is particularly important to understand the historical context(s) that affect contemporary policy.

\section{The Gap between Theory and Application and its Relevance for Policy}

The context of historically contingent evolution or "path dependence" has been applied extensively to studying processes of change from evolutionary biology to social dynamics (see David 2007). Despite the theoretical acceptance of historical details providing a useful measure of precision to descriptions of dynamic systems, a lot of policy (and economic) analysis continues to be done ahistorically, as though the events of the past have no significant and persistent impact on unfolding events. Explaining the subtle relationship among values, institutions, economics, and medicine that has shaped the health system in the United States, Rosemary Stevens, Charles E. Rosenberg and Lawton R. Burns (2006) define the nature of contemporary public policies as follows:

Policies on the ground seem less a coherent package of ideas and logically related practices than a layered conglomerate of stalemated battles, ad hoc allegiances, and ideological gradients, more cumulative sediment of negotiated ceasefires among powerful stakeholders than a self-conscious commitment to data- sanctioned goals. (p. 13)

Moreover, they contend that in as much as contemporary public policy is derived from ideological invocations of the past, it is as much a structured contention as history. Therefore, while policy-making process moulds new realities, it is itself moulded by pre-existing institutions and contestations. Further, as Ha-Joon Chang (2011) points out in the context of the discourse on institutions and development, poor understanding of changes in institutions has led to unduly optimistic or pessimistic positions about the feasibility of institutional reform, once again establishing the importance of historical understanding for policy making.

Applying this relationship between policy and history in the Indian context is very instructive. Despite decades of public policy in independent India, progress on the issue of gender equality appears stalled, and even regressed in some instance (see Sen 2013). Persistent gender inequality in India is signified by the limited economic and social options for women (Duflo 2012), high mortality rates of girls and women, and sex-selective abortions (Sen 2003), low levels of education and economic independence of women (Sen \& Grown 2013), and violence against women in the domestic sphere (Dalal \& Lindqvist 2010; Yee 2013) and public spaces (Raj \& McDougal 2014).

Amartya Sen in his monographs on missing women (1992 and 2003) noted the puzzling discrepancy of trends that divide the country into two disparate geographical halves. The northern and western states of India have a sex ratio significantly below the international benchmark, and much higher instances of sex-selective abortions, compared to the southern and eastern states. The economically eclectic mix of states in these two halves means that this discrepancy cannot be explained by income levels, economic growth, female education, or even 
religious background. Perhaps we need to explore historical patterns from a policy perspective to find the explanation for persistent gender inequality in India, as well as these stark regional exceptions.

Combining historical research with public policy allows us to explore questions such as: What are the scales, agents, and mechanisms of socio-cultural transformations in a region? Momentous popular movements, such as those related to decolonization, anti-slavery, civil rights, etc., created unprecedented social spaces for the political involvement of women in various parts of the world. Then why did the old social/cultural status quo return in the decades following such transformative movements, often with a vengeance? What accounts for the neglect of the role, scale, and agency of women in mainstream historical narratives? How does this erasure of women affect the social and political climate in which public policies are designed, debated and implemented?

The relevance of the interplay of history and policy is evident when we consider contemporary gender scenario in most regions of the world, not just in India. In this context, the stories of the non-elite women could prove to be critical, not only in providing a nuanced understanding of the nature and scale of women's involvement in historical movements, but also as instructive accounts tracing continuities and changes in the socio-political context of social policies. Ordinary lives, of men and women, are inexorably intertwined with the unfolding historical processes of the time. Unless these connections are made apparent in all variety of historical narratives, every generation is doomed to fight the same battles for equality and justice over and over again. Nowhere is this irony more apparent than in the persistent invisibility of women's role in human history.

\section{Historical 'Gender Mainstreaming'}

There is clearly the need to discover and preserve more women's records, not only to write more ‘women's histories', but more importantly, to broaden the conceptual and narrative frameworks of mainstream historical traditions. This could be referred to as `historical gender mainstreaming'. In this usage, the term has overlaps with the United Nations' definition of 'gender mainstreaming' as a response to problems caused by gender inequality, not using gender as an 'add-on' at some stage of a project's development, but involving the knowledge and awareness of gender in all phases of policies and programmes (WHO 2014). The 1995 Beijing Declaration at the Fourth UN World Conference on Women endorsed gender mainstreaming as critical for achieving gender equality commitments (United Nations 1995). Recognized as a globally accepted fundamental right, and a necessary condition for the achievement of the objectives of growth, employment and social cohesion, gender mainstreaming as a strategy to achieve equality between women and men has been around for more than two decades. Subsequently, gender mainstreaming has been adopted by many member nations as a comprehensive approach, pertaining to all activities in peace, development and human rights, to ensure that women and men can influence, participate in, and benefit equally from positive 
change. Despite such targeted policy interventions, gender discrimination and inequality remain deeply entrenched worldwide, be it in barriers to access to health (Payne 2011), development objectives (Unterhalter 2013), or political representation (Paxton, et al 2009).

Indeed gender mainstreaming as an approach is not without its detractors, among policymakers and feminists alike. Feminist scholars critique it for its limited ability to further foundational feminist goals such as transformation of the patriarchal culture or de-essentialising gender beyond just women's issues. This approach is also criticised for enabling the co-opting of the feminist movement by the forces of the post-Fordist economic system, which needs women's labour and a more educated work force (Jensen 2006; Stratigaki 2005). Others point to the hierarchical institutional contexts internationally and domestically, which continue to play a decisive role in policy making without taking into account the complex intersections of gender, nationality, and social exclusions (see Awoyemi and Oluwatayo 2010; Molen \& Novikova 2005). This is not to suggest that a political economy approach is more likely to work where critical approaches such as subaltern studies and feminism have failed, but a combination of the these approaches might bring about more fundamental shifts. Since, clearly, the robust debates in subaltern studies and feminism have had limited impact on making the 'women-free' conceptual frameworks of disparate historiographical traditions more inclusive.

Perhaps one explanation for the lack of progress on this front may be in the linguisticcum-literary turn experienced by both Subaltern Studies (Sarkar 1999) and in feminist history writing (Canning 1994). Linguistic turn denotes the historical analysis of 'representation' as opposed to the pursuit of a discernible, retrievable historical 'reality'. This literary turn led to very useful critiques of established historical paradigms, narratives, and chronologies, encompassing poststructuralist literary criticism, linguistic theory, philosophy, cultural anthropology, and gender history. However, there has also been a downside to this trend: As language and textuality occupied a central position in poststructuralist historical analysis, the emphasis shifted away from social reality or historical context, to `language’ as constituting historical events and human consciousness.

New domains of interdisciplinary inquiry opened in the wake of the literary turn, interrogating historical methods and practices, decentering the Western white male subject, and challenging the unreflective use of concepts such as experience, agency, discourse or identity. As Canning (1994) explains, initially, these literary critiques "opened up an emancipatory space in which feminist historians could constitute female subjects while exposing and rectifying the historical exclusion of women and the identification of human with male.” However, long after the provocative question of Sojourner Truth “Ain’t I a woman” (1851), the totalizing and inherently racist discourses in Western feminism led to further deconstruction of the category of 'woman'(see for instance Mohanty 1991). While this uncovering of hierarchies, binaries, and colonization led to feminists of colour rewriting histories of slavery, colonialism, and feminism from their own oppositional locations, it has done little to insert gender as an essential category of historical analysis in mainstream/national/global historiographical traditions. 
In fact, the post-structuralist turn informed by linguistic analysis came to be seen as a particularly disempowering approach for marginalized groups to adopt. Its focus on conceptualization of processes, categories, and contemplation of differences were seen to undermine their efforts to be subjects rather than objects of history (Hartsock 1990). Within Subaltern Studies, this period concomitantly saw a retreat from the agendas of radical change, and questions of inequality or subjugation (Sarkar, 1999 and 2002). All in all, it would appear that the task of recovering the female/subaltern subject and render her/him visible in social history had become secondary to the dialectics of multiple and indeterminate identities. Therefore, despite excellent feminist texts exposing the collective amnesia regarding the setbacks and victories of women in the struggle against their sub-humanization, critical traditions such as Subaltern Studies and feminist approaches to history writing continue to pose only limited challenges to the vastly more influential national narratives, orientalist images, ethnic stereotype, and Hindu majoritarian accounts of history in India, which dominate library shelves and reading lists, and where women remain marginal at best ${ }^{12}$.

Moreover, reclaiming the historical role of non-elite women does more than just broaden our historical horizons; it provides a solid historical grounding to understand contemporary trends of persistence inequality and injustices in a society. In the context of rising sexual, social, and economic violence against women in almost every parts of the world, it is important to question the historical invisibility of women in mainstream historical narratives, whether we are examining the causes and effects of economic development or political freedom.

Somewhat eschewing the very valid critique of gender mainstreaming above, it can be argued that women are already part of the 'mainstream' of social and political change, but that their repeated and systematic erasure from historical accounts conveys a diminished sense of their contribution to an interconnected global history. Combining a critical political economy approach with 'historical grounding' could therefore provide a fuller historical understanding of the past, as well as new strategies to address current challenges to public policy.

\section{Conclusion}

Rancière argued for the right of the ordinary person to be listened to and a celebration of the profound usefulness of learning from what the ordinary person has to say, unmediated as far as possible by the intervention of the more powerful (Hewlett 2010, p. 86). The erasure of women's role human history and the many mechanisms of silencing their stories in various contexts acquire significant salience in contemporary times where the gulf between the histories of peoples and the state is likely to widen further. This rift is aided by many contemporary trends: rapid economic globalization, the neoliberal retreat of the state, intensification of the competition over the control of natural resources, the concentration of capital at a level outside the effective control of states, and the emergence of new sites of resistance. 
Clearly, the historical invisibility of women not only warps historical understanding, but also undoubtedly influences contemporary perceptions, debates, designs, and thus outcomes of social and public policy. Moreover, the ongoing chasm between critical scholarship and its 'application' noted in this article is another obstacle to an inclusive and just approach. This gap between theory and practice inordinately exists in many fields, not just in history. For instance, this pattern is evident in the field of Global Studies (GLST), where the propensity to consider 'global’ processes in a geographically, culturally, and historically limited space stubbornly persists in the teaching of GLST as shown in a survey of courses and major textbooks (Shrivastava 2008). These trends are particularly perplexing in view of the vigorous body of critical theoretical analysis striving for a deeper understanding of our interconnected global world in the scholarly realm (see Pieterse 2013).

The inclusion of the variegated experiences of history can only enrich our understanding of historical processes and their interplay with individual lives in the past and the present. The significance of these individual stories goes beyond providing historical material, as seen in the great examples of the Book of Negores (Hill 2011) and Kiss of the Fur Queen (Highway 1999) individual stories based on dialectic rigour and historical research. With astonishing immediacy and urgency, these stories bring home the cruelty of slavery and the residential schools in Canada respectively. In this context then, stories of ordinary women who participated in historical movements/moments acquire specific salience. By acknowledging the representational character of all stories about the past, we can begin to broaden our understanding of the context in which meanings related to nations, cultures, genders, identity, and political economy are continually produced, reshaped, and/or erased.

The poetess Gangasati provides a poignant if largely unacknowledged example that highlights the endemic nature of women's invisibility in historical recounting. Writing in the twelfth-century in western India she was the first to use the word Harijan, some two hundred years before Narsimh Mehta and seven hundred years before Mahatma Gandhi popularized the term to refer to the so-called untouchable castes of India (see Tharu \& Lalita, 1991, pp. 87-89). In a poem addressed to her daughter-in-law urging that she remain resolute in her convictions, Gangasati used the term Harijan to refer to all of God's children. She thus points to an oft repeated challenge to the subjugated status of women, particularly those who do not have social, ethnic, or political privileges: Is she not a child of God?

\section{Notes}

1) Daniel Woolf (2011) describes the imposition of European historical methods and scholarship on the rest of the world as 'Clio's Empire'. He provides a detailed account of the uprooting of several preexisting modes of historicity through the formidable western imperial apparatus, particularly in British India. 
2) Amma's Daughters is the narrative historical biography of Prakashwati Sinha (Amma) and Rajeshwar Narayan Sinha (Babu) told in their daughter's voice (Rekha or Surekha Sinha). At the time of writing this article, the manuscript was submitted to Athabasca University Press for publication as an open source book.

3) In addition to the extraordinarily constructive comments of the two anonymous reviewers, the arguments for this article evolved out of the following papers presented. I am grateful to the numerous commentators who provided feedback:

a. "Subaltern Approach and the "Sense" of History in Global Studies", The Cosmopolitan Ideal: Challenges and Opportunities, Global Studies Association, University of Roehampton, London, July 10-12, 2013.

b. Contemporary Global Studies and Historical Subaltern Studies: A Mutually Inspiring Relationship”, Sixth Global Studies Conference, India International Centre, New Delhi, Sept 5-7, 2013.

c. "Mainstreaming the role of Women in History Writing", the Swedish South Asian Studies Network (SASNET) Language, Culture and Values: East and West Conference in New Delhi, India, December 16-18, 2014.

4) I would like to express my sincere gratitude to the exceptional lead curator at the British Library in London, Dr. Antonia Moon, and the Director of Bihar State Archives, Dr. Vijoy Kumar in Patna.

5) This is a summary of my grandmother's life distilled from her unpublished personal diary and the published autobiography (Sinha n.d, and 1962), both written in Hindi. Subsequent to my grandmother's passing in 1972, my mother preserved many oral historical strands in her own writings (particularly in Sinha 2011).

6) My grandmother's silence regarding the family of her birth confirms my suspicion that she was rejected by her family. Nevertheless, she acquired a vast adoptive family in UP, Rajasthan, and Maharashtra of 'brothers' and 'sisters' from a variety of backgrounds. My mother referred to these connections as our 'freedom-fighter-family'. My siblings and I remain very close to these families, but the next generation knows little about the history of these relationships that fall too far out of the 'normal' social structures.

7) These materials became the basis for a historical narrative biography Amma's Daughters.

8) My mother and I read many of these intimate and moving diaries before they eventually became home and feed for generations of mice and silverfish within our neglected family library. The surviving diary is a valuable window into a woman's perilous journey through a complex social and political maze which appears unchanging across time and space. This diary has been digitized and will be placed in a public archive, along with other remaining letters and photographs which recorded the intricate overlapping of a national movement with individual lives.

9) As Uma Narayan (1998) points out, however, we need to be attentive to the role "of historical and political processes by which particular values and practices have come to be imputed as central or definitive of a particular "culture"." For instance, the label of "Indian culture" was imposed on an assortment of political territories on the subcontinent, thereby subsuming the plurality of histories, cultural artifacts, and practices under an arbitrary and unchanging frame deployed by colonialists towards a political project. Narayan highlights this pointedly in her analysis of the construction of Sati or Suttee - the practice of a widow's immolation - as "a central and authentic Indian tradition". Ahistorical and culturally essentialist nineteenth century debates between British colonialists and Indian elite helped the rare practice of Sati to acquire an emblematic status; now available for deployment as a lofty ideal of womanhood by contemporary Hindu fundamentalists. Narayan urges us to question "how and why this particular practice which is not engaged in by the vast majority of Hindu communities let alone all India ones, and which was the exception rather than the routine fate of widows even in the few communities that practiced it, came to be regarded as a "Central Indian Tradition” (p. 93).” 
10) One of these confidential reports (British Library 1930) mentions the "intemperate" effects of the speeches of Shanti Devi of Muttra at meetings held under the auspices of the Congress. It also notes the emergence of a new phenomenon "meetings for women only" which are very well attended. My grandmother records her arrest for sedition on August 13, 1930 in Ajmer after a spell of public speeches (Sinha 1962, pp. 7-14). She was a twelve year old girl living in Mathura (Muttra) under the name 'Shanti Devi', and was hosted by a benefactor's family in Ajmer at the time of her arrest.

11) See Barnett (1993) for the role of the constraints of gender, race, and class in silencing women's role in another context.

12) For instance see Vijaya Ramaswamy (2011) for an extensive analysis of the omissions of women from political, economic, and even social accounts, within various traditions of South Indian historiography.

\section{Notes on Contributor}

Meenal Shrivastava earned her degrees in Modern Indian History (MA, Rajasthan University, Jaipur) and International Studies (M.Phil and Ph. D, Jawaharlal Nehru University, New Delhi) between 1990 and 1998. Subsequently, she taught at the department of International Relations, University of the Witwatersrand, Johannesburg from 2000-2006. Currently, she is Professor and Academic Coordinator for Political Economy and Global Studies at Athabasca University, Canada. Her research interests include various aspects and agents of globalization as seen through the lenses of International Political Economy and the emerging field of Global Studies. She was editor of Politikon: South African Journal of Political Studies (Routledge) from 2007-2010 and has served on the editorial boards of Politikon, Athabasca University Press, International Environmental Review, Alternate Routes, and The ARDENT. Additionally, she has served on several governance boards such as for the Parkland Institute, Canadian Political Science Association, and the South African Association of Political Studies.

\section{References}

Agarwal, M.G. (2008). Freedom Fighters of India (in 4 volumes). New Delhi: Gyan.

Awoyemi, T.T. and Oluwatayo, I.B. (2010). Gender Mainstreaming of ICT Projects: Lessons from Rural Southwest Nigeria. Libyan Agriculture Research Center Journal International, 1 (2), 65-69.

Bakshi, S.R. (1977). Simon Commission and Indian Nationalism. New Delhi: M.M Publishers.

Bannerji, Himani. (2000). Projects of Hegemony: Towards a critique of subaltern Studies' ‘Resolution of the Women's question'. Economic and Political Weekly, 35(11), 902-920.

Barnett, Bernice McNair. (1993). Invisible Southern Black Women Leaders in the Civil Rights Movement: The Triple Constraints of Gender, Race and Class. Gender and Society, 7(2), 162182. 
Basu, Aparna and Ray, Bharti. (1990). Women's Struggle: A History of the All India Women's Conference 1927-1990. New Delhi: Manohar.

British Library. (1930). Confidential memorandum on the internal situation in Rajputana and Ajmer-Merwara for the period ending the $15^{\text {th }}$ August 1930, No. 53-C/187-GL/28, 465-PC/30

British Library. (1931). Suggestions for dealing with women who take part in the civil disobedience campaign, Confidential Report, Bengal Secretariat, Political Department. IOR/L/PJ/4727

Canning, Kathleen. (1994). Feminist History after the Linguistic Turn: Historicizing Discourse and Experience, Signs, 19(2), 368-404.

Chang, Ha-Joon. (2011). Institutions and economic development: theory, policy and history. Journal of Institutional Economics, 7 (4), 473-498.

Chatterjee, Partha. (1993). The Nation and Its Fragments: Colonial and Post-Colonial Histories. New Jersey: Princeton University Press.

Chatterjee, Partha. (1989). The nationalist resolution of the women's question. In K. Sangari and S. Vaid (eds.) Recasting Women: Essays in Colonial History (pp. 233-253). New Delhi: Kali for Women.

Childs, Sarah. (2008). Women and British Party Politics: Descriptive, substantive, and symbolic representation. London \& New York: Routledge.

Dalal, Koustuv and Kent Lindqvist. (2010). A National Study of the Prevalence and Correlates of Domestic Violence in India. Asia Pacific Journal of Public Health, 24(2), 265-277.

David, Paul A. (2007). Path Dependence - A Foundational Concept for Historical Social Science. Cliometrica, 1(2), 91-114.

Desai, Neera and Usha Thakkar. (2001). Women in Indian Society. New Delhi: National Book Trust.

Díaz-Andreu, Magarita and Marie Louise Stig Sorensen. (2013). Excavating Women: A History of Women in European Archeology. Oxford: Routledge.

Duflo, Esther. (2012). Women's Empowerment and Economic Development. Journal of Economic Literature, 50(4), 1051-79.

Fletcher, Ian Christopher, Philippa Levine, Laura E. Nym Mayhall (eds.). (2014). Women's Suffrage in the British Empire: Citizenship, Nation, and Race. London: Routledge. 
Forbes, Geraldine. (1988). The Politics of Respectability: Indian Women and the Indian National Congress. In D.A. Low (ed.) The Indian National Congress: Centenary Hindsight (pp. 54-97). Delhi: Oxford University Press.

Forbes, Geraldine. (1999). Women in Modern India. Cambridge: Cambridge University Press.

Freedman, Estelle. (2007). The Essential Feminist Reader. New York: Modern Library.

Hewlett, Nick. (2010). Badiou, Balibar, Rancière: Rethinking Emancipation. London: A\&C Black.

Highway, Tomson. (1999). Kiss of the Fur Queen. Toronto: Anchor.

Hill, Lawrence. (2011). Book of Negroes. Toronto: Harper Collins.

Holmes, Richard. (2010, November 21). The Royal Society’s Lost Women Scientists. The Observer.

Retrieved from http://www.theguardian.com/science/2010/nov/21/royal-society-lost-women$\underline{\text { scientists }}$

Holmes, Rachel. (2014). Eleanor Marx: A Life. New York: Bloomsbury.

Jena, Indira. (1999). Her Story: A Narration of Women in the National Freedom Struggle in Orissa and Bihar. New Delhi: Pustak Mandir.

Jenson, Jane. (2006). The European Social Model: Gender and Generational Equality. In Giddens, Anthony et al (ed.). Global Europe, Social Europe (pp. 151-171). Cambridge: Polity.

Kapur, Ratna. (2000). Law and the Sexual Subaltern: A Comparative Perspective. Cleveland State Law Review, 48 (1), 15-23.

Kumar, Radha. (1993). A History of Doing: an Illustrated Account of Movements for Women's Rights and Feminist in India 1800-1990. London: Verso Books.

Legg, Stephen. (2014). Prostitution and the Ends of the Empire: Scale, Governmentalities and Interwar India. Durham: Duke University.

Legg, Stephen. (2003). Gendered Politics and Nationalised Homes: Women and the anti-colonial struggle in Delhi, 1930-47. Gender, Place and Culture: A Journal of Feminist Geography, 10 (1), 7-27. 
Lerner, Gerda. (2005). The Majority Finds its Past: Placing Women in History. Chapel Hill: UNC Press.

Lerner, Gerda. (1994). The Creation of Feminist Consciousness: From the Middle Ages to Eighteen Seventy. Oxford: Oxford University Press.

Menon, Nivedita. (2007). Sexualities. London: Zed Books.

Mohanty, Chandra, A. Russo and L. Torres (eds.). (1991). Cartographies of Struggle: Third World Women and the Politics of Feminism. Bloomington: Indiana University Press.

Molen, Irna van der and Novikova, Irina. (2005). Mainstreaming gender in the EUaccession process: the case of the Baltic Republics. Journal of European Social Policy, 15(2), 139-156.

Narayan, Uma. (1998). Essence of Culture and a Sense of History: A Feminist Critique of Cultural Essentialism. Hypatia, 13 (2), 86-106.

National Archives of India (NAI) (1932) The Congress Women-Volunteer Case of Benaras: A Criticism of the District Magistrate's Judgement by Madan Mohan Malaviya, 267/216-276/POL.

O’Hanlon, Rosalind. (1988). Recovering the Subject: Subaltern Studies and Histories of Resistance in Colonial South Asia. Modern Asian Studies, 22 (1), 189-224.

Pandey, Gyanendra (ed.). (2011). Subalternity and Difference: Investigations from the North and the South. London: Routledge.

Paxton, Pamela, Melanie M. Hughes, Mathew A. Painter. (2009). Growth in Women's Political Representation: A Longitudinal Exploration of Democracy, Electoral Systems and Gender Quotas. European Journal of Political Research, 49(1), 25-52.

Pieterse, Jan Nederveen. (2010). What is Global Studies? Globalizations, 10(4), 499-514.

Raj, Anita and Lotus McDougal. (2014). Sexual Violence and Rape in India. The Lancet, 383 (9920), 865.

Ramaswamy, Vijaya. (2011). Gender and the Writing of South Indian History. In Sabyasachi Bhattacharya (Ed.). Approaches to History: Essays in Indian Historiography (pp. 199-224). New Delhi: ICHR. 
Sangari, Kumkum and Sudesh Vaid (eds.). (1990). Recasting Women: Essays in Indian Colonial History. New Jersey: Rutgers University Press.

Sarkar, Sumit. (2002). Beyond Nationalist Frames: Relocating Postmodernism, Hindutva, History. New Delhi: Permanent Black.

Sarkar, Sumit. (1999). Post-Modernism and the Writing of History. Studies in History, 15(2), 293-322.

Sarkar, Sumit. (1998). Writing Social History. New Delhi: Oxford University.

Sarkar, Sumit. (1983a). "Popular Movements” and "Middle Class” Leadership in Late Colonial India: Perspectives and Problems of a "History from Below". Calcutta: Centre for Studies in the Social Sciences.

Sarkar, Sumit. (1983b). Modern India: 1885-1947. New Delhi and London: MacMillan.

Sen, Amartya. (2013, October 10). India's Women: The Mixed Truth. The New York Review of Books. Retrieved from http://www.nybooks.com/articles/archives/2013/oct/10/indias-womenmixed-truth/?pagination=false

Sen, Amartya. (2003). Missing Women - Revisited. British Medical Journal, 327 (7427), 12971298.

Sen, Amartya. (1992). Missing Women. British Medical Journal, 304 (6827), 587-588.

Sen, Gita \& Caren Grown. (2013). Development Crisis and Alternative Visions: Third World Women's Perspectives. Oxford: Routledge.

Shrivastava, Meenal. (2008). Globalizing ‘Global Studies’: Vehicle for Disciplinary and Regional Bridges? New Global Studies, 2 (3), Article 5, 1-22.

Shrivastava, Meenal. (forthcoming). Amma's Daughters. Edmonton: Athabasca University Press.

Sinha, Mrinalini. (2008). Gender in the Critiques of Colonialism and Nationalism: Locating the "Indian Woman". In Sarkar, Sumit and Tanika Sarkar (Ed.). Women and Social Reform in Modern India: A Reader (pp. 452-472). Bloomington: Indiana University.

Sinha, Mrinalini. (2006). Spectres of Mother India: The Global Restructuring of an Empire. Durham: Duke University.

Sinha, Prakashwati. (1962). Smriti ki Shrinkhalayen [Shackles or Serialization of My Memories]. Jaipur: Vaishali Press. 
Sinha, Prakashwati. (n.d). Personal journal written from August 24, 1927 with periodic entries until 1957. Private Collection.

Sinha, Surekha. (2011). Us Dhoop ki Chhaanh [Cool Shades in the Scorching Sun]. Jaipur: Sahityagar Prakashan.

Sinha, Surekha. (2008a). Pahari Baba [Sage on the Mountain]. Jaipur: Sahityagar Prakashan.

Sinha, Surekha. (2008b). Man ki Pukaar [The Heart Calls]. Jaipur: Sahityagar Prakashan.

Sinha, Surekha. (2008c). Sangeet Chintan [A Meditation on Music]. Jaipur: Panchsheel

Prakashan.

Spivak, Gayatri C. (1985). Subaltern Studies: Deconstructing Historiography. In R. Guha (ed.). Subaltern Studies IV (pp. 330-363). New Delhi: Oxford University.

Stevens, Rosemary, Charles E. Rosenberg and Lawton R. Burns. (2006). History and Health Policy in the United States: Putting the Past Back In. New York: Rutgers University.

Stratigaki, Maria. (2005). Gender Mainstreaming vs Positive Action: An Ongoing Conflict in EU Gender Equality Policy. European Journal of Women's Studies, 12 (2), 165-186.

Thapar-Björkert, Suruchi. (2006). Women in the Indian National Movement: Unseen Faces and unheard Voices, 1930-42. Bristol: University of Bristol.

Tharu, Susie J. and K. Lalita. (1991). Women Writing in India: Sixth Century B.C to Early Twentieth Century. New York: Feminist Press at CUNY.

Thomas, P. (1964). Indian Women through the Ages. Bombay: Asia Publishing.

Truth, Sojourner. (1851). Speech to the Akron Convention 1851. Retrieved from http://web.archive.org/web/20061229183544/http://www.suffragist.com/docs.htm

United Nations. (1995). Beijing Declaration and Platform for Action”. The Fourth World Conference on Women. Retrieved from

http://www.un.org/womenwatch/daw/beijing/pdf/BDPfA\%20E.pdf

Unterhalter, Elaine. (2013). Poverty, Education, Gender, and the Millennium Development Goals: Reflections on Boundaries and Intersectionality. Theory and Research in Education. 10(3), 253-274. 
Wolfe, Daniel. (2011). A Global History of History. Cambridge: Cambridge University Press.

World Health Organization (WHO). (2014). What is Gender Mainstreaming. Retrieved from http://www.who.int/gender/gender_mainstreaming/en/

Yee, Amy. (2013). Reforms Urged to Tackle Violence against Women in India. The Lancet, 381 (9876), 1445-1446. 